\title{
Sociology as the Philosophy of the Future
}

\author{
Antoni Lindgren ${ }^{1}$ \\ ${ }^{1}$ Department of Economy, Technology and Society, Luelå University of Technology, Luleå, Sweden \\ Correspondence: Antoni Lindgren, Associate professor/Senior lecturer in Sociology, Department of Economy, \\ Technology and Society, Luelå University of Technology, SE-97187 Luleå, Sweden. E-mail: \\ Antoni.lindgren@ltu.se
}

Received: January 13, 2012

Accepted: April 10, $2012 \quad$ Published: July 1, 2012

doi:10.5539/ass.v8n8p45

URL: http://dx.doi.org/10.5539/ass.v8n8p45

\begin{abstract}
In the beginning of sociology it was a philosophy for promoting the Good society. Sociology was what we in Feuerbach's terms may call a "philosophy of the future". The German enlightenment is crucial if one wants to go beyond: create an alternative to today's sociology. Kant's notion of experience bridges the abyss created by the empiricists and rationalists by placing knowledge in man. Sociology is very much a heritage of the French Enlightenment, Auguste Comte (1798-1857) and Emile Durkhein (1858-1917). They thought of themselves as positivists, i.e., as doing something "objective". At the same time as heirs of the ideas of Enlightenment they wanted sociology to be used in order to improve society, to create a Good society. Comte had a view of this whole - society - in terms of Man. Lost in Durkheim is this idea of man developing in and through society, reflecting a change in the social context, in the development of the capitalist society. After the death of Durkheim in 1917 sociology holds a marginal position in the French society but then in the late 1940's it rises again and in this new sociology American sociology was dominating, becoming an applied science. Today sociology continues this empiricist tradition. It is claimed that society has become something out-of-control. Instead we should follow its French and German roots. Understanding society as a reflection of ourselves, of man is what we need in order to create a Good society for everyone, this also should be the first principle of sociology as the philosophy of the future.
\end{abstract}

Keywords: sociology, philosophy, future

\section{Introduction}

In the beginning of sociology it was a philosophy for promoting the Good society (Lindgren 2011a). Sociology was - what we in Feuerbach's terms may call - a "philosophy of the future" (cf. Feuerbach 1843).The conclusion in this article is that this sociology can become once more: we just need to reflect on: regain our - today lost understanding of what philosophy and society is. Taking the point of departure in the early $19^{\text {th }}$ century philosophy (Kant, Hegel, Feuerbach etc) it here is argued that society is a creation of man as man and that the Good society is a society where people can be human: feel good. This - that a good society is a (feeling) good society - may sound as a tautology but - and this is where philosophy comes in - it is only an effect of rhetorics (cf. Lindgren 2011b, 2011c). If we want to, we can understand society and what the good society is but to do this we need to go beyond rhetorics - go to ourselves: man inside us. This philosophy can teach us.

\section{Knowledge and Human Experience}

The German Enlightenment - especially Kant and Hegel - is crucial if one wants to go beyond: create an alternative to today's sociology. The critique of Kant solves the mystery of knowledge that Hume (1743) had described shortly before him, i.e., that in order to know something you already have to know it. Hume's discussion was related to explanations in terms of cause and effect i.e., in order to explain something you must take the possibility of explanation - i.e., the existence of causes - for granted. The cause is not a part of the sensuous: empirical world but - and this is where Kant's contribution lies - it: the cause still is part of our experience of the world. Kant's notion of experience then bridges the abyss created by the empiricists and rationalists grounding knowledge either on the body/sensations (cf. Berkeley 1710) or on the soul/thinking (cf. Descartes 1641). Kant instead places knowledge in our faculty of knowledge (1781). Thus, in a sense empiricism and rationalism are both right, though only partly. Here Hegel (1760-1831) adds his contribution to - our philosophical understanding of - knowledge in the form of dialectics. In his Logics of science (1812) he 
describes the development of knowledge as part of human history. Using dialectics knowledge - and society: to him the state - develops by overcoming contradictions in reality. The future knowledge - and society - thus rests on the past as well as the present society. The seeds of the future are present today. Sociology - originally was and once again - can be the philosophy of this future society.

\subsection{The Philosophy of the Future}

Hegel represents the optimism of philosophy and society in the Age of Enlightenment (cf. Hampson 1968). Here philosophy and society are one. This gave a solid optimism to his followers, especially in the "young". Philosophy was no longer only a "Philosophy": i.e., an explanation of the world but to Feuerbach (1843), Marx (1845) and others (cf. Solomon and Higgins 1993) philosophy was a part of the world. There was in reach of humanity a putting an end to blind history (Hegel 1807) and the beginning of an era of human freedom.

\section{Sociology as a Science of Society}

Sociology is very much a heritage of the - French - Enlightenment. It is quite common to say that sociology starts with August Comte (1798-1857). He is "the father of sociology". There were others using the word "sociology" at that time but he is the one being attributed to having coined the word "sociology" as the name of the new science he then was about to develop. Though there were more people involved - Saint-Simon, Tocqueville and Montesquieu (cf. Aron 1965) to take the today well known - Comte was the most important creator of sociology. Emile Durkheim (1858-1917) was also important - for the rhetorical legitimating of sociology - since it was he who established sociology as a science. Basically Durkheim was propagating Comte's ideas only in other words. Comte - as the creator of sociology as a "Religion of Humanity" - was during his life-time and for a long time after a too controversial figure to be accepted by the intellectual elites in France at that time. Thus sociology starts with both Comte and Durkheim.

\subsection{Capitalism and Sociology}

Important in the creation of sociology is also the social context where it was developed. Sociology - as the science of society - is developed at the same time as society is changing into "capitalism". This new kind of society both Comte and Durkheim are discussing as the society of their time: as industrial society and organic society respectively. Another word for this society is "capitalism" - a word already used by Saint-Simon (1765-1825) and later Marx (1818-83) - and historically it is at the same time as historians date this new society (cf. Hobsbawn 1962). "Capitalism" is also the word we generally know this kind of society in today.

Then sociology, society and capitalism are different words used for the same phenomena: that thing which we may call capitalism. There is no coincidence in that the creation of sociology as a new science - which is about society as its "object" - takes place at the same time as the emergence of the capitalist society. In fact sociology as a science is a self-understanding of the capitalist society (Lindgren 2011a). Sociology is basically the self-understanding of capitalism.

\section{Ideology and Sociology}

Then, if sociology is the self-understanding of capitalism it is also an ideology of capitalism. The word "ideology" is a creation of the early $19^{\text {th }}$ century, in France meaning people - i.e., intellectuals - taking a standpoint in terms of their views on society and propagating this view. Comte - and Durkheim - though thought of themselves as positivists", i.e., as doing something "objective". They thought of sociology as a science: as something objective, i.e., different from ideology. At the same time - as heirs of the ideas of Enlightenment they wanted sociology to be used in order to improve society, to create a Good society (Lindgren 2011a). Comte and Durkheim also thought that the "development" of society was something "objective" and their goal, aim was to make this good development possible, by reforming society. Their view of society was that the development was a harmonious process which sociology could contribute to in a consensus since everyone would at the end have to agree on the necessity of reforms. As Frenchmen - and born rationalists - they believed in rationality, that reason at the end will rule.

\subsection{Positivism}

Comte was thinking of sociology as a science in terms of positivism. Sometimes he used positivism as a synonymous word to sociology. He believed that sociology as a science was about observing reality and discovering patterns then to be followed and promoted. This resembles the ideal of later $20^{\text {th }}$ century science but he was not interested in explanation in theoretical terms - of metaphysics - e.g., in terms of the mechanical laws of Newton. At the same time he thought that there was an ongoing development of different sciences through-out history, starting with astronomy, mathematic etc ending lately with positivism/sociology. In the future this development would culminate in a science of religion which he later also used the name positivism for, i.e., 
indicating sociology's future role of replacing religion. Meantime during this development there was a change in the scientifique method from analytic sciences - physics, chemistry etc - to holistic: synthetic sciences like biology, sociology. In synthetic sciences parts are explained by the whole. Though he himself did not use the word "function" this was his kind of understanding society (cf. Aron 1965).

\subsection{The Whole}

At the same time he had a view of this whole - when it came to society - in terms of Man. He used the two concepts "statics" and "dynamics": order and development to describe this whole. He thought - cf. the Hegelians in Germany - that through-out the human history a natural order was slowly evolving. His proverb for the Religion of Humanity: "Progress is the development of order" is expressing this thought. Thus order, this structure, the statics of society was the same as the structure, nature of man (Comte 1848, Aron 1965). Man is, according to Comte threefold: heart, will and reason or to make it simpler; heart, hands and mind (cf. Dewey 1916). In society the family stands for heart, work stands for hands and religion for mind. Just like in a single individual these faculties must be in harmony they must be in harmony in the Good society.

\subsection{The Good Society}

In Comte's sociology there is inherent an idea that the aim and goal of the development is the good, human society, i.e., that the goal of history is the fulfilment of man. Thus the goal of sociology is to facilitate: help bring about this development of human order. Others expressing this same idea about society at the same time as Comte are Marx (1845), Feuerbach (1841) and Kirkegaard (1846). Sociology is about observing this development of society and sociology has the goal to be promoting the good society. Thus, in the development of science and sociology there is - besides the (functional) understanding - also an explanation of society in terms of the goal of history.

\section{Organic Society}

Another aspect of sociology is that to Durkheim (1893) society is something living, organic: society is to be explained - it's development - functionally. Also - in agreement to science - he is adding a causal explanation. Modern - organic - society is functional because the social division of labour makes it possible for more people to survive. At the same the social division of labour is explained as an effect of the increase in the population density (i.e., its cause).

\subsection{Science and Society}

The difference between Comte's and Durkheim's views of society is Comte's teleological: goal related explanation and Durkheim's causal explanation. The difference is a difference in the kind of science. Though in Durkheim's later writings - on science and religion - the idea of man returns in the guise of society: i.e., that man in religion really worships himself as society compared to Comte here in Durkheim the idea of society has replaced the idea of man as a society. Instead of being a self expression of man as in Comte to Durkheim society is something both organic: living and objective: an assembly of facts. Lost in Durkheim is also the - cf. Hegel (1807) - idea of man developing in and through society. The biological: functional and scientifique: causal explanations of Durkheim are replacing the Comtean understanding of sociology and society. Here - in the view of society as something "objective" or something human - there is a difference between Durkheim and Comte.

\subsection{Capitalism and Colonialism}

This difference between Comte and Durkheim is reflecting a change in the social context, in society: in the development of the capitalist society. At the end of the $19^{\text {th }}$ century Neo-Darwinism was created as an ideology legitimating colonisation in terms of "the survival of the strongest" people/race (Callinicos 1999). This "competition" - and racism - legitimated both capitalism (society as being based on individual competition) and colonialism (subordination of other "inferior" societies). Durkheim's sociology is a critique: a response to this capitalistic - interpretation of Darwin. Compared to Neo-Darwinism there is a different - biological - idea of development in Durkheim. Here it is society that lives, that is the living thing; less important are the individuals in society. Compared to the original idea of Darwin, though there is a similarity in that to Darwin it is nature that selects the fittest individuals and thus - similar to Durkheim - society comes first: creates its "fit" members. Also, compared to Comte's sociology the sociology of Durkheim is no longer about man in society but - there is an opposite idea - deals with the need of society; i.e., to instil society in man. To Durkheim the individual is an effect: a cause of society. 


\section{The New Sociology}

After the death of Durkheim in 1917 sociology holds a marginal position in the French society and never recovers the grandeur position it had during Durkheim's time. The same happens in Germany - where Tönnies, Weber and Simmel had been prominent sociologists - and in the rest of Europe. Then, in the late 1940's it raises again, like the Bird Fenix, though it is not really the same now as before. (cf. Manicacs 1988). In this new sociology American sociology was dominating. Structural functionalism was the main theory here and this was at a first glance very similar to the thought of Durkheim on society in terms of functions and an organic, living structure. Society was something more than the individuals and had its own functions. Also like Comte and Durkheim the normal state of affairs is harmony, consensus and the role of sociology is to be a tool in the stabilisation, normal functioning of society. Sociology is also a science like in Durkheim i.e., objective: factual and causal. Sociology gets with Lazarsfelts statistical survey techniques and methods of measurements an identity as an applied - special - science just as the positivists in Vienna had imagined (the Vienna circle, 1929).

\subsection{Pure Science}

In the late 1950'sthe American sociologist C Wright Mills (1959) criticized this sociology for being either abstracted empiricism or empty theory. Instead, according to him sociology was to be based - once more like in the classics of sociology: Marx, Durkheim and Weber - on the experience of ordinary people making the creation of the good, democratic society possible. Still though, the American kind of sociology also became the European sociology. The difference of this new sociology compared to the sociology of Comte and Durkheim is the abstract and empirical notion of society. Society as something social has been replaced by "development" development of everything - in a linear, limitless sense of eternal growth etc (Lindgren 2005). Gone is the organic society, left is "life" - but empty, "abstract", i.e., it is just a word - discussed in terms of "development". Life - the driving force in all development - is abstracted from what we spontaneously understand by something "living", i.e., a human, animal etc. There are no life-forms, just the "living", the process e.g., cf. "artificial life, artificial intelligence" etc. The facts are also - like development - abstracted from us humans, instead the empirical, statistical etc facts have become an empirical world in themselves.

\subsection{Rationality as Profit-making}

The American sociologist Talcott Parsons (1902-79) is the famous sociologist at this time and he had re-read the Italian sociologist Wilfredo Pareto (1848-1923) - who had the idea that the rational maximisation principle, optimization principal was prevailing in society- and that is the root of Parsons later ideas about abstract "modernisation". He had also re-read the German sociologist Max Weber and the idea of modernisation is here close to Weber's idea of rationality, i.e., as mean-end instrumentality. Weber saw this rationality as being "typical" of "the Spirit of Capitalism. That is - to both Pareto and Weber - the typical of capitalism was the rational, profit calculus and profit making; i.e., maximisation of profit. Also the Neo-Darwinist ideas of the English sociologist Herbert Spencer were re-used in explaining the development of society in terms of individual competition Thus, in the late 60 's life has become the same as a pure - formless - content: the rational calculus, a mathematical algorithm just as in the heads of propagators of artificial intelligence (cf. March and Simon 1957). Sociology had become a pure science (cf. Kant 1781).

\section{Today's Sociology}

Today - sociology as a self-understanding of a society - continues the abstract empiricist tradition. It is claimed that society has become something out-of-control, a risk society (Beck 1986, 1994) etc and forcing people to be self-reflective (cf. Lasch 1994). The hope - in this desperate situation - is either just to keep on moving in the tiny faith of that society is a creation of us in the routines of everyday life (Giddens 1984) or to set the hope for a better future on a "better" pragmatic arguing, i.e., communicative "action" (cf. Habermas 1981)). Thus, there are no truths, just an ever going on struggle, without purpose and less hope. People are fighting with themselves, i.e., their identity keeping themselves together in terms of gender, nationality, workplace etc (Beck, Giddens and Lasch 1994). This situation is forcing people to a constant, ever struggling - individual - "fitting-in". Meanwhile, at the same time sociology - as "an evidence-based" i.e., empirical science - goes on as a business as usual, as an unproblematic gathering and analysis of data, objective facts. Thus sociology remains as abstract and empirical as C Wright Mills (1959) described it 50 years ago.

\section{Conclusion}

Instead we should once more make sociology into the philosophy of the future. Following its French and German roots this is quite simple to do. Understanding society as a reflection of ourselves, of man what we need in order to create a Good society is to start with being ourselves, expressing our hearts, hands and minds in a way 
that we feel is good. Good is good for everyone and by using our mind we can understand that the Good society we must all have, i.e., together and that it is a good thing to strive for. Thus: be good! is the first principle of sociology as the philosophy of the future.(cf. Lindgren 2012)

\section{References}

Alex Callinicos. (1999). Social Theory: A Historical Introduction. USA: New York University Press.

Allan Janik, \& Stephen Toulmin. (1973). Wittgenstein's Vienna. Chicago: Elephant Paperbacks.

Anthony Giddens. (1984). The Constitution of Society: Outline of the Theory of Structuration. UK: Polity Press.

Antoni Lindgren. (2005). Människan och samhället. Till kritiken av den senmoderna retoriken. Uddevalla: Bokförlaget i Baktsjaur.

Antoni Lindgren. (2011a). Science and Sociology. Asian Social Science, 7(6), June.

Antoni Lindgren. (2011b). Education, Culture and Vocation. Riga: Bokförlaget i Baktsjaur.

Antoni Lindgren. (2011c). Miscellanea: the New Science. Riga: Bokförlaget i Baktsjaur.

Antoni Lindgren. (2012). Reflections on the Art of Exclusion in Stefanie Stolz and Phillip Gonon Challenges and Reforms in Vocational Education. Switzerland: Peter Lang.

Auguste Comte. (1848). Discourse sur l'ensemble du positivisme. Paris: GF Flammarion.

C Wright Mills. (1959). Den sociologiska visionen. Lund: Arkiv förlag.

Emile Durkheim. (1893). The Social Division of Labor in Society. USA: The Free Press.

Emile Durkheim. (1897). Självmordet. Lund: Argos.

Emile Durkhem. (1895). Sociologins metodregler. Göteborg: Korpen förlag.

Georg Friedrich Hegel. (1812). The Science of Logics. UK: Cambridge University Press.

Georg Simmel. (1908). The Problem Areas of Sociology in Kurt H. Wolf: The sociology of Georg Simmel. London: The Free Press.

Georg Willhelm Friedrich Hegel. (1807). The Phenomenology of Spirit. UK: Oxford University Press.

Georg Willhelm Friedrich Hegel. (1892). Lectures on the Philosophy of History. Retrieved January 10, 2012, from www.marxist.org

Hume, David. (1843). An Enquiry Concerning Human Understanding. La Salle: Open Court.

Immanuel Kant. (1781). Kritik av det rena förnuftet. Stockholm: Thales.

Jurgen Habermas. (1997). Diskurs, rätt och demokrati: politisk-filosofiska texter. Uddevalla: Daidalos.

Karl Marx. (1845). Teser om Feuerbach. Retrieved January 10, 2012, from www.marxist.org

Kathleen M Higgins \& Robert C Solomon. (ed) (1993). The Age of German Idealism. UK: Routledge.

Ludwig Feuerbach. (1841). The essence of Christianity. N.Y.: Prometheus Books.

Ludwig Feuerbach. (1843). Principles of the Philosophy of The Future. USA: Hackett Publishing Co.

Max Weber. (1912). Samhällsvetenskapens objektivitet $i$ Tre klassiska texter. Göteborg: Korpen förlag.

Max Weber. (1918). Göteborg: Politik som yrke i Tre klassiska texter. Korpen förlag.

Norman Hampson. (1968). Upplysningen. Brutus Östlings Bokförlag Symposion. Stockholm/Stehag.

Peter T. Manicas. (1987). A History and Philosophy of the Social Sciences. UK: Basil Blackwell.

Raymond Aron. (1965). Main Currents in Sociological Thought 1-2. UK: Penguin Books.

Sören Kirkegaard. (1846). Ovetenskaplig efterskrift i Sören Kirkegaard i urval. Uddevalla: Forum.

Ulrich Beck, Anthony Giddens \& Scott Lash. (1994). Politics, Tradition and Aesthetics in the Modern Social order. UK: Polity Press.

Ulrich Beck. (1986). Risk Society: Towards a New Modernity. UK: Sage Publications Ltd. 